\title{
Isolation and culture of glandular epithelial and stromal cells from the endometrium of mares
}

\author{
E. D. Watson*, E. S. Aubrey, H. G. Zanecosky and P. L. Sertich \\ University of Pennsylvania School of Veterinary Medicine, New Bolton Center, Kennett Square, \\ PA 19348, USA
}

\begin{abstract}
Summary. Glandular epithelial and stromal cells were isolated from the endometrium of mares by collagenase digestion and were incubated on plastic for 7-9 days until the cells formed confluent monolayers. The cells differed in morphology: epithelial cells appeared polyhedral and stromal cells were spindle like. The monolayers were incubated in the presence and absence of oxytocin. Medium was removed from wells after 2,8 and $24 \mathrm{~h}$ of incubation. Concentrations of prostaglandin $\mathrm{F}$ (PGF) in the medium increased significantly during this time. Glandular epithelial cells produced significantly more PGF than did stromal cells. Both types of cell responded significantly to oxytocin stimulation by increased secretion of PGF; the response of glandular epithelial cells tended to be greater than that of stromal cells. Secretion of PGF by cultured cells was not affected by cycle stage or pregnancy.
\end{abstract}

Keywords: endometrium; cell culture; prostaglandins; horse

\section{Introduction}

There is strong circumstantial evidence that prostaglandin $F_{2 a}\left(P F_{2 a}\right)$ from the endometrium of nonpregnant mares is responsible for the demise of the corpus luteum near the end of dioestrus. In pregnant mares, the conceptus exerts an early inhibitory effect on the release of $\mathrm{PGF}_{2 \alpha}$ from the endometrium (Berglund et al., 1982; Sharp et al., 1989; Watson \& Sertich, 1989). Oxytocin may be involved as an intermediary in release of PGF $_{2 \alpha}$ in mares (Goff et al., 1987) as it is in other species (Ginther et al., 1967; Roberts et al., 1975). It has been suggested that the response of the endometrium to oxytocin may differ in pregnant and nonpregnant mares (Goff et al., 1987; Franklin et al., 1989).

Although studies have been performed involving incubation of endometrial tissue in mares, little is known of the contribution of individual endometrial components to the events that occur during the oestrous cycle and at the time of maternal recognition of pregnancy. The endometrium is a complex tissue consisting of several types of cell. Investigation of the contribution of individual types of cell and the interactions between types of cell can be studied in vitro using primary cell cultures. In other species, epithelial and stromal cells from the endometrium have been shown to possess different characteristics with regard to growth in culture, sex steroid receptors (McCormack \& Glasser, 1980; Varma et al., 1982) and adenylate cyclase activity (Fortier et al., 1987, 1988). In the present study, we isolated glandular epithelial cells and stromal cells from the mare endometrium and measured release of PGF by monolayers of these cells cultured in the presence and absence of oxytocin.

*Present address: Department of Veterinary Clinical Studies, Royal (Dick) School of Veterinary Studies, Veterinary Field Station, nr Roslin, Midlothian EH25 9RG, UK. 


\title{
Materials and Methods
}

\begin{abstract}
Animals
Twelve mares of mixed breed weighing $450-550 \mathrm{~kg}$ were teased daily with a stallion. From the first day of oestrus, follicular development was monitored once a day by ovarian palpation and ultrasonography per rectum until signs of ovulation were detected. Day of ovulation was designated day 0 . Endometrial biopsy samples $(n=4$, approximately $1 \mathrm{~g}$ of tissue) were collected from the mares on day 3 of oestrus, days 10 or 14 of dioestrus, or day 14 of pregnancy. If samples were biopsied from a mare on more than one occasion, at least 12 days intervened between sample collections. Some of the mares were bred by artificial insemination during oestrus using semen from a fertile stallion and were confirmed pregnant by ultrasonic detection of an embryo before collection of endometrial biopsy samples on day 14 .
\end{abstract}

\section{Isolation of endometrial cells}

Endometrial glands and stromal cells were isolated by a modification of the method described by Satyaswaroop $e t$ al. (1979) using reagents purchased from Sigma Chemical Co. (St Louis, MO, USA). The tissues were placed in cold Ham's F10 medium containing $2 \mathrm{mmol} \mathrm{L-glutamine} 1^{-1}$ and 50 iu penicillin plus $50 \mu \mathrm{g}$ streptomycin ml $\mathrm{m}^{-1}$ until they arrived at the laboratory. The tissue was chopped into fragments of about $1 \mathrm{~mm}^{3}$. Tissue fragments were disrupted further by gentle, repeated pipetting. The tissue was resuspended in Ham's F10 containing $30 \%$ heat treated newborn calf serum, 50 iu penicillin plus $50 \mu \mathrm{g}$ streptomycin $\mathrm{ml}^{-1}, 2 \mathrm{mmol} \mathrm{L}$-glutamine $!^{-1}, 1.5 \mathrm{mg}$ collagenase Type I (Sigma Chemical Co.) and $20 \mathrm{mmol}$ Hepes $1^{-1}$. The suspensions were incubated at $39^{\circ} \mathrm{C}$ in a humidified atmosphere of $5 \%$ $\mathrm{CO}_{2}: 95 \%$ air with agitation every $15 \mathrm{~min}$. Digestion was periodically monitored by decanting a small volume of the suspension into a sterile tissue culture dish and visualizing the isolated glands under an inverted microscope. Digestion was allowed to continue until only an occasional stromal cell was left adhering to the glands (usually within I $-2 \mathrm{~h}$ ). After incubation, red blood cells were removed by filtering the suspension through sterile gauze into a sterile polypropylene centrifuge tube. The cell suspension was then allowed to sediment for $10 \mathrm{~min}$; during this time the glands settled on the bottom of the tube and the stromal cells remained in suspension. The supernatant containing the stromal cells was then removed and placed into a separate tube and centrifuged for $10 \mathrm{~min}$ at $200 \mathrm{~g}$. Cells were resuspended in fresh medium (without collagenase) containing $10 \%$ newborn calf serum and any remaining glands were allowed to sediment. Sedimentation and washing were repeated twice. The supernatant containing mainly stromal cells was examined under an inverted microscope. If gland fragments were seen, the suspension was centrifuged at $100 \mathrm{~g}$ for $1 \mathrm{~min}$ to remove the gland fragments.

The gland pellet obtained from the first sedimentation step was resuspended in fresh medium containing $10 \%$ newborn calf serum and allowed to sediment. The supernatant was discarded and the process repeated 6-7 times to ensure a clean gland preparation.

Glands and stromal cells were each finally resuspended in medium containing $10 \%$ newborn calf serum. One millilitre of suspension was added to each of 18 wells of a 24-well tissue culture plate (Corning Glass Works, Corning, NY, USA) and incubated at $39^{\circ} \mathrm{C}$ in a humidified atmosphere of $5 \% \mathrm{CO}_{2}: 95 \%$ air. At $24 \mathrm{~h}, 1 \mathrm{ml}$ of fresh medium was added and at $72-96 \mathrm{~h}$ the medium was changed. Cultures were incubated until a confluent monolayer was obtained (approximately 7-9 days), at which time the medium was removed. Fresh medium was added to control wells and medium containing oxytocin $(1 \mu \mathrm{g})$ was added to replicate wells. The medium was removed from these wells after 2,8 and $24 \mathrm{~h}$ (triplicate wells per time point), centrifuged at $3000 \mathrm{~g}$ for $10 \mathrm{~min}$ at $4^{\circ} \mathrm{C}$ and the supernatant stored in aliquots at $-70^{\circ} \mathrm{C}$.

After the medium was removed, $0 \cdot 1 \%$ Triton X-100 was added to the wells and the cells were disrupted and detached from the plastic with the aid of a plastic scraper. The cell suspension was frozen at $-20^{\circ} \mathrm{C}$ until assayed for protein concentrations using the method described by Lowry et al. (1951).

\section{PGF assay}

Medium was assayed directly for PGF using a previously validated technique (Watson \& Sertich, 1989) with the exception that a different antibody (Sigma Chemical Co.) was used. Crossreactivity was less than $0.1 \%$ with all PGs tested except for $\mathrm{PGF}_{1 \alpha}\left(60 \%\right.$ crossreactivity). Because of the high crossreactivity of the antiserum with $\mathrm{PGF}_{1 \mathrm{l}}$, results are reported as total immunoreactive PGF. Although the relative concentrations of the ' $F$ ' fraction of prostaglandins have not been measured in mare endometrium, in the rat uterus the predominant prostaglandin was PGF $_{2 a}$ with only trace amounts of $\mathbf{P G F}_{1 a}$ (Fenwick et al., 1977). It seems probable therefore that a major proportion of the PGF measured in this study was $\mathbf{P G F}_{2 a}$. Limit of sensitivity of the assay was $0.1 \mathrm{ng}$ per tube. Intra- and interassay coefficients of variation were $10.3 \%$ and $8.7 \%$, respectively. The coefficient of correlation between amount recovered: amount added was 0.993 and regression analysis yielded an equation of $y=1.09 x-15.65$.

\section{Statistical analysis}

Analysis of variance for repeated measures was used to evaluate the effects of stage of cycle, tissue type, treatment and time on concentrations of PGF. When indicated by the analysis of variance, Scheffe's test was used to make pairwise comparisons of means. A significance level of $P<0.05$ was used for all statistical tests. 
(a)

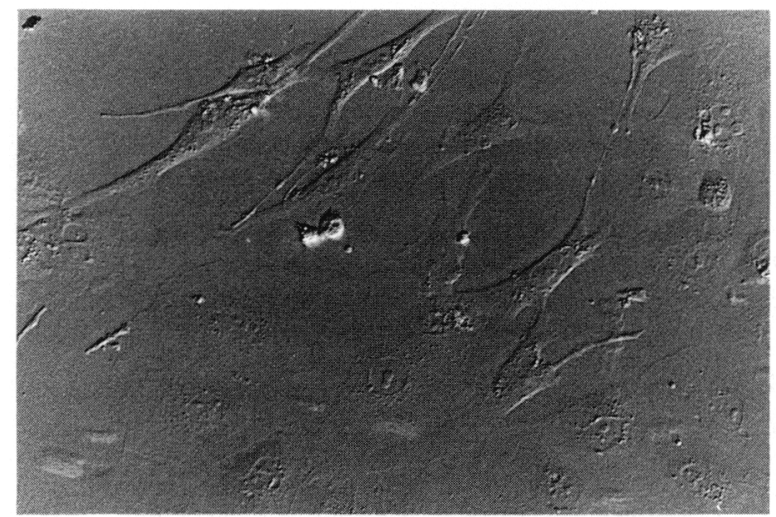

(b)

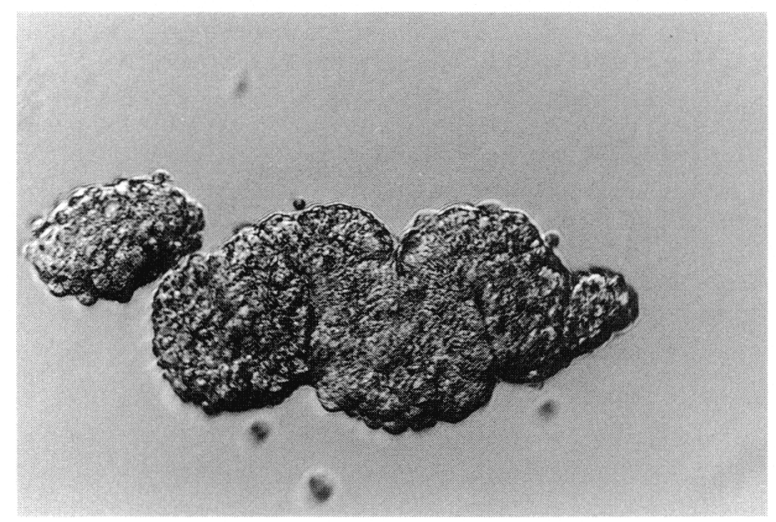

(c)

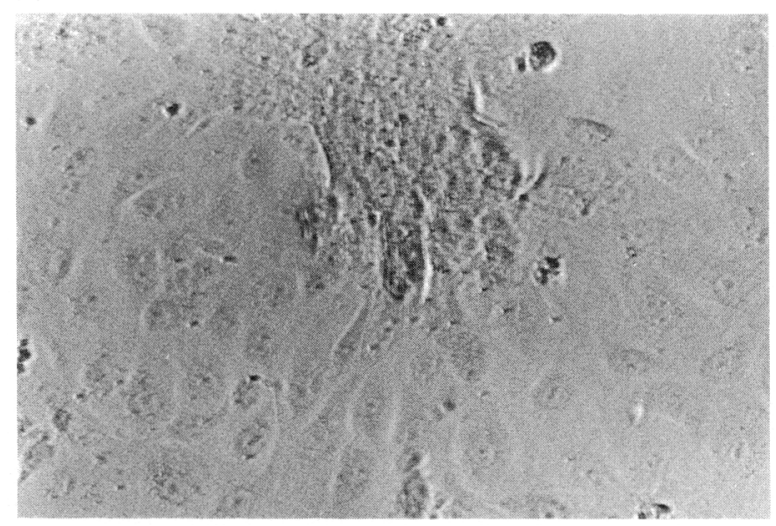

Fig. 1. Different stages of culture of isolated cells from mare endometrium: (a) stromal cells on day 2 of culture, (b) isolated glands and (c) gland collapsed with epithelial cells spreading and forming monolayer on day 2 of culture. Hoffman Modulation Contrast System, $\times 22$.

\section{Results}

Examination by microscope throughout the culture period revealed that stromal and epithelial cells differed in morphology and cross-contamination of each cell type was judged to be $<5 \%$. More 
than $95 \%$ of the stromal cells were viable at the time of plating based on trypan blue exclusion. Cell preparations consisted of either single cells or small clumps of cells. Stromal cells attached to the plastic by $24 \mathrm{~h}$, and by day 2 cells were spreading and were spindle-shaped and fibroblast-like in appearance (Fig. 1a). After day 2, they rapidly spread to confluence.

Isolated glands were readily visualized under the microscope and were contaminated by a few stromal cells (Fig. 1b). By $24 \mathrm{~h}$ after plating, the glands had collapsed and a monolayer of cells was growing radially from each gland explant (Fig. 1c). Most of the gland cells within the monolayers were polyhedral, but some were elongated.

There was a significant $(P<0.01)$ interaction between type of cell and time in concentrations of PGF measured in culture supernatant, indicating that PGF production over time was different for epithelial and stromal cells (Figs 2 and 3). Mean PGF production for the two types of cell was compared at 2, 8 and $24 \mathrm{~h}$ and the mean PGF concentration for the three periods was compared for each type of cell.

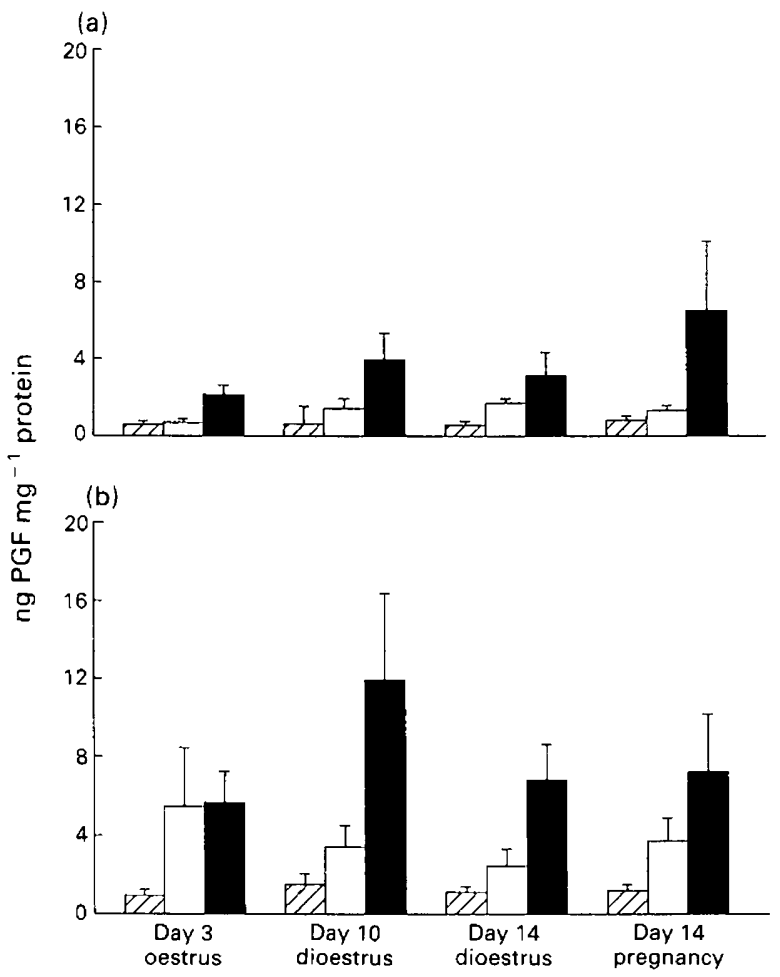

Fig. 2. Production of prostaglandin $F$ (mean \pm SEM) by a monolayer of mare endometrial glandular epithelial cells (a) in the absence and (b) in the presence of oxytocin. Supernatants were sampled at $2(\square), 8(\square)$ and $24(\square)$ h after addition of fresh culture medium. Each point represents the mean of triplicate cell preparations from three to eight mares.

For glandular epithelial cells, there was a significant difference in mean PGF concentrations between 2 and $24 \mathrm{~h}$ and between 8 and $24 \mathrm{~h}$. For stromal cells, there was a significant difference in mean PGF concentrations only between 2 and $24 \mathrm{~h}$.

There was no difference in PGF production between glandular epithelial and stromal cells at either 2 or $8 \mathrm{~h}$, but by $24 \mathrm{~h}$, epithelial cells had produced significantly more PGF than stromal cells. 


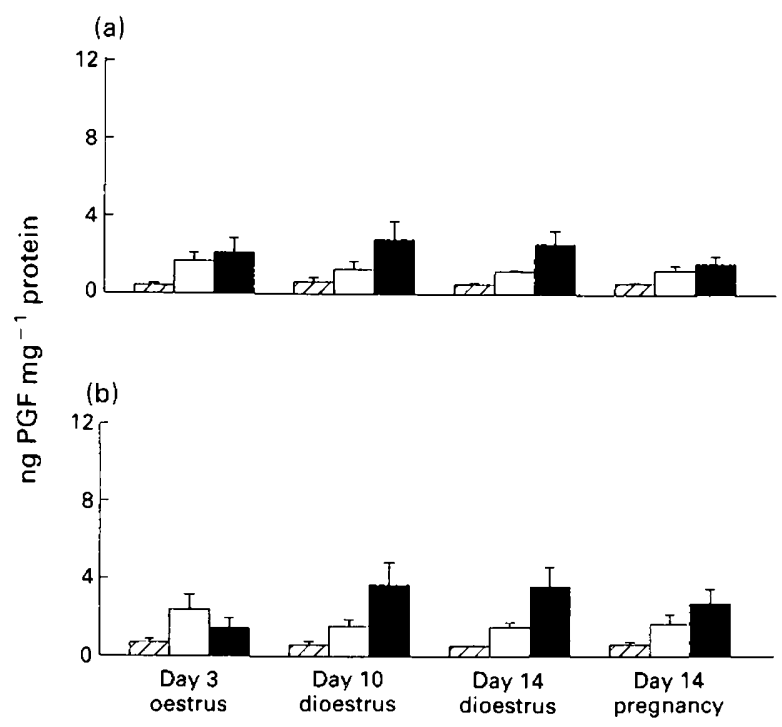

Fig. 3. Production of prostaglandin F (mean \pm SEM) by a monolayer of stromal cells (a) in the absence and (b) in the presence of oxytocin. Supernatants were collected or sampled at 2 ( $\square), 8$ $(\square)$ and $24(\boldsymbol{\square}) \mathrm{h}$ after addition of fresh culture medium. Each point represents the mean of triplicate cell preparations from three to eight mares.

Stage of cycle and pregnancy did not significantly affect production of PGF by glandular epithelial or stromal cells. Oxytocin treatment significantly $(P<0.01)$ stimulated PGF secretion by both types of cell at all times, but the glandular epithelial cells tended $(P=0.053)$ to respond more than stromal cells (Figs 2 and 3).

\section{Discussion}

Isolation and monolayer culture of endometrial stromal and epithelial cells has previously been reported in women (Satyaswaroop et al., 1979; Casey et al., 1985), cows (Fortier et al., 1988), ewes (Cherny \& Findlay, 1990) and rabbits (Ricketts et al., 1983), but not in mares. Reported morphology was comparable across species, and similar to the results for endometrium of mares in our study. In other species, cell morphology has been shown to correlate well with immunohistological identification of cell markers and with identification of cells at an ultrastructural level (Satyaswaroop et al., 1979; Varma et al., 1982; Ricketts et al., 1983; Cherny \& Findlay, 1990). In our study, the stromal cell cultures did not appear to be contaminated with epithelial cells, presumably because they quickly overgrew any contaminating cells. By contrast, some cultures of glandular epithelial cells contained some fibroblast-like cells. Because glands always retained a few adherent stromal cells after the separation procedure, it is likely that these cells were the contaminating fibroblastlike cells. However, it has also been reported that epithelial cells tend to be pleomorphic after culture and some may appear spindle shaped resembling fibroblasts (Satyaswaroop et al., 1979).

Previously, release of PGF by equine endometrium has been measured in harvested medium after incubation of endometrial tissue (Vernon et al., 1981; Berglund et al., 1982; Watson \& Sertich, 1989) or tissue perfusion (Franklin et al., 1989). In these studies, it was not possible to identify the cellular source of the PGF. By isolating types of cell, we showed that after incubation for $24 \mathrm{~h}$, glandular epithelial cells had produced more PGF than had stromal cells. Isolated endometrial epithelial cells from the ewe and cow released most of the PGF from the endometrium (Fortier et al., 1988; Cherny \& Findlay, 1990), whereas in human endometrium it is not clear whether stromal 
cells (Casey et al., 1985; Gal et al., 1982) or glandular epithelial cells (Schatz et al., 1985; Smith \& Kelly, 1988) are the major producers of PGF.

In the present study, concentrations of PGF significantly increased between 2 and $24 \mathrm{~h}$ after addition of fresh medium. Treatment of cell monolayers with oxytocin tended to produce a greater response in cultures of glandular epithelial cells than in stromal cells. The higher production of PGF by glandular epithelial cells along with the trend towards increased responsiveness to oxytocin may indicate that, in the mare, the epithelial cells are a more important source of PGF at luteolysis than are the stromal cells. The differences observed in production of PGF also help to confirm that two different cell populations were indeed being studied. Basal production of and release of PGF after oxytocin stimulation were not affected by pregnancy or stage of oestrous cycle when the tissue was collected. By contrast, short-term incubations of endometrium from mares produced greater concentrations of PGF during mid- to late dioestrus than at other stages of the cycle (Vernon et al., 1981). In agreement with the findings of the present study, other workers have found no difference in basal production of PGF by endometrium from nonpregnant or early pregnant mares (Berglund et al., 1982; Watson \& Sertich, 1989; Franklin et al., 1989). In our study, there was no statistical difference in response to oxytocin between cells from pregnant and nonpregnant mares 14 days after ovulation. Although there was no difference in mean concentrations of PGF between the control and oxytocintreated glandular epithelial cells from pregnant mares after $24 \mathrm{~h}$ of incubation, mean PGF concentrations in control cultures were increased by one set of cultures which contained extremely high concentrations of PGF. Pairwise comparisons showed that there was a statistically significant increase in PGF concentrations in oxytocin-treated wells. Oxytocin is considered to be involved in luteolysis in the mare. Oxytocin binding by the endometrium of the nonpregnant mare increased during days 14-17 after ovulation (Stull \& Evans, 1986). Administration of oxytocin to mares about the time of luteolysis stimulated release of $\mathrm{PGF}_{2 a}$ from the endometrium (Betteridge et al., 1985; Goff et al., 1987); however, this response appeared to be inhibited in pregnant mares (Goff et al., 1987). Similarly, in vitro treatment with oxytocin did not stimulate the release of PGF from perfused endometrium from pregnant mares (Franklin et al., 1989). It is not clear why cultured endometrial cells from pregnant mares responded to treatment with oxytocin. Perhaps culturing the cells for 7 days altered the ability of the cells to respond to oxytocin, or perhaps lack of stromal-epithelial cell interactions modified the response. It is also possible that luminal and glandular epithelium may exhibit different patterns of secretion and, therefore, that the results of the present study cannot be compared with data from perfusion experiments or experiments using isolated luminal epithelium.

In conclusion, monolayers of glandular epithelial cells produced more PGF than stromal cells and PGF production was not affected by stage of cycle. Regardless of the pregnancy status of the mare at the time samples were obtained, the glandular epithelial and stromal cells responded to treatment with oxytocin. Further work with such monolayers will be necessary to investigate the manner in which substances produced by the conceptus interfere with synthesis of PGF by the endometrium of pregnant mares.

This work was supported by the Dorothy Russell Havemeyer Foundation, E. S. Aubrey was a Dorothy Russell Havemeyer Summer Research Assistant. We thank P. G. Satyaswaroop, Hershey Medical Center, Hershey, PA, for advice on cell separation and culture technique, R. M. Oristaglio for assisting with ovarian palpation and procurement of endometrial biopsy tissues, and $P$. Spencer for performing the statistical analysis.

\section{References}

Berglund, L.A., Sharp, D.C., Vernon, M.W. \& Thatcher, W.W. (1982) Effect of pregnancy and collection techniques on prostaglandin $F$ in the uterine lumen of pony mares. Journal of Reproduction and Fertility Supplement 32, 335-341.
Betteridge, K.J., Renard, A. \& Goff, A.K. (1985) Uterine prostaglandin release relative to embryo collection, transfer procedures and maintenance of the corpus luteum. Equine Veterinary Journal Supplement 3, $25-33$. 
Casey, M.L., Gal, D., Korte, K., Okita, J.R., MacDonald, P.C. \& Mitchell, M.D. (1985) Metabolism of arachidonic acid by human endometrial glands and stromal cells maintained in monolayer culture. In Mechanism of Menstrual Bleeding, pp. 107-127. Eds D. T. Baird \& E. A. Michie. Raven Press, New York.

Cherny, R.A. \& Findlay, J.K. (1990) Separation and culture of ovine endometrial epithelial and stromal cells: evidence of morphological and functional polarity. Biology of Reproduction 43, 241-250.

Fenwick, L., Jones, R.L., Naylor, B., Poyser, N.L. \& Wilson, N.H. (1977) Production of prostaglandins by the pseudopregnant rat uterus, in vitro, and the effect of tamoxifen with the identification of 6-ketoprostaglandin $\mathrm{F}-\mathrm{I} \alpha$ as a major product. British Journal of Pharmacology 59, 191-199.

Fortier, M.A., Boulanger, M., Bowlet, A. P. \& Lambert, R.D. (1987) Cell specific localization of prostaglandin E-2 sensitive adenylate cyclase in rabbit endometrium. Biology of Reproduction 36, 10251033.

Fortier, M.A., Guibalt, L.A. \& Grasso, F. (1988) Specific properties of epithelial and stromal cells from the endometrium of cows. Journal of Reproduction and Fertility 83, 293-248.

Franklin, K.J., Gross, T.S., Dubois, D.H. \& Sharp, D.C. (1989) In vitro prostaglandin secretion from luminal and myometrial sides of endometrium from cyclic and pregnant mares at day 14 post-estrus. Biology of Reproduction 40, Supplement 1, Abstract 199.

Gal, D., Casey, L.M., Johnston, J.M. \& MacDonald, P.C. (1982) Mesenchyme-epithelial interactions in human endometrium. Prostaglandin synthesis in separated cell types. Journal of Clinical Investigation 70, 789-805.

Ginther, O.J., Woody, C.O., Mahajan, S., Janakiraman, K. \& Casida, L.E. (1967) Effect of oxytocin administration on the oestrous cycle of unilaterally hysterectomized heifers. Journal of Reproduction and Fertility 14, 225-229.

Goff, A.K., Pontbriand, D. \& Sirois, J. (1987) Oxytocin stimulation of plasma 15-keto-13,14-dihydro prostaglandin F-2 $\alpha$ during the oestrous cycle and early pregnancy in the mare. Journal of Reproduction and Fertility Supplement 35, 253-260.

Lowry, O.H., Rosebrough, N.J., Farr, A.L. \& Randall, R.J. (1951) Protein measurements with the Folin phenol reagent. Journal of Biological Chemistry 193 , 252-275.
McCormack, S.A. \& Glasser, S.R. (1980) Differential response of individual uterine cell types from immature rats treated with estradiol. Endocrinology 106, 1634-1649.

Ricketts, A.P., Hagensee, M. \& Bullock, D.W. (1983) Characterization in primary monolayer culture of separated cell types from rabbit endometrium. Journal of Reproduction and Fertility 67, 151-160.

Roberts, J.S., Barcikowski, B., Wilson, L., Skarnes, C. \& McCracken, J.A. (1975) Hormonal and related factors affecting the release of prostaglandin $F-2 \alpha$ from the uterus. Journal of Steroid Biochemistry 6, 1091-1097.

Satyaswaroop, P.G., Bressler, R.S., de la Pena, M.M. \& Gurpide, E. (1979) Isolation and culture of human endometrial glands. Endocrinology 48, 639-641.

Schatz, F., Markiewicz, L., Barg, P. \& Girpide, E. (1985) In vitro effects of ovarian steroids on prostaglandin $\mathrm{F}$ $2 \alpha$ output by human endometrium and endometrial epithelial cells. Journal of Clinical Endocrinology and Metabolism 61, 361-367.

Sharp, D.C., McDowell, K.J., Weithenauer, J. \& Thatcher, W.W. (1989) The continuum of events leading to maternal recognition of pregnancy in mares. Journal of Reproduction and Fertility Supplement 37, 101-107.

Smith, S.K. \& Kelly, R.W. (1988) The release of PGF-2 $\alpha$ and PGE-2 from separated cells of human endometrium and decidua. Prostaglandins, Leukotrienes and Essential Fatty Acids 33, 91-96.

Stull, A. \& Evans, J.W. (1986) Oxytocin binding in the uterus of the cycling mare. Journal of Equine Veterinary Science 6, 114-119.

Varma, V.A., Melin, S.A., Adamec, T.A., Dorman, B.H., Siegfried, J.M., Walton, L.A., Carney, C.N., Norton, C.R. \& Kaufman, D.G. (1982) Monolayer culture of human endometrium: methods of culture and identification of cell types. In Vitro 18, 911-918.

Vernon, M.W., Zavy, M.T., Asquith, R.L. \& Sharp, D.C. (1981) Prostaglandin F-2 $\alpha$ in the equine endometrium: steroid modulation and production capacities during the estrous cycle and early pregnancy. Biology of Reproduction 25, 581-589.

Watson, E.D. \& Sertich, P.L. (1989) Prostaglandin production by horse embryos and the effect of coculture of embryos with endometrium from pregnant mares. Journal of Reproduction and Fertility 87, 331-336. 